material to enable indifferent teachers to teach well. The Russian science teachers are teaching as much science in less time than their British counterparts due to the fact that the teacher is given more guidance and far more aids to teaching. If the means of teaching science subjects more efficiently were available, the English schoolmaster might achieve much more in fewer periode and the shortage of teachers might not be so acute.

In the U.S.S.R. there are research institutes for devising school experiments and designing apparatus. In England this is usually done by the busy schoolmaster in any spare moments he may have, and, as Mr. Lewis states, "We cannot afford to continue in this amateurish way". Not only is the Russian teacher provided with a complete set of demonstration apparatus for his course, but he is well supplied with films on the subjects being taught. All this does much to help the teacher: it does not impede the good teacher from developing his own ideas, but it does enable the indifferent teacher to achieve a minimum standard, to teach with a minimum of efficiency.

Another serious problem is that, in England, the assumption is made that a young man merely has to take his science degree and can then teach for the next thirty years without ever returning for further instruction, refreshment or guidance. In the United States last year more than 17,000 high school science teachers attended summer institutes. In England, less than a hundred attended Ministry of Education courses for grammar school science teachers. The American summor institutes last from six to eight weeks; the courses in Britain usually last less than at fortnight.

Mr. Lewis has dealt with some of the problems confronting science education in England to-day. They are serious indeed if England, and Britain as a whole, is not to lag far behind what is being done in other countries.

\title{
EXPERIMENT IN EXAMINING FIRST-YEAR CHEMISTRY STUDENTS
}

$I^{N}$ teaching chemistry, as with other scientific disciplines, there is a number of objectives. More often than not these objectives remain implicit in the minds of the lecturers. If they are made more explicit, it is usually in rather inexact and personal terms.

A general taxonomy of educational objectives has been developed by B. S. Bloom and others at the University of Chicago which contains six major classes: (1) knowledge; (2) comprehension; (3) application; (4) analysis; (5) synthesis; (6) evaluation. These six classes are subdivided, defined and illustrated by example. Several members of the University of Melbourne Chemistry Department explored the adequacy of this taxonomy for chemistry applying it to old examination papers, and the following simplification of Bloom's definitions of classes was produced:

(1) Knowledge, involves simply the recall of material directly taught.

(2) Comprehension, involves understanding of the material taught, to the extent that it is recognized when presented in any form.

(3) Application, involves the use of such material in a new situation.

(4) Analysis, where the breakdown into detail involves both the facts and their relation in a new situation.

(5) Synthesis, where previously presented material is assembled to create something new.

(6) Evaluation, involves judgments using undefined criteria about values in a chemical situation.

These categories, so defined, were found to cover most questions on a number of examination papers, although one question would often involve the components of several classes.

With this experience as a basis, a first-year paper was set covering all six classes. The questions were so designed that the percentage marks obtained for oach class were easily extracted from the total, in the course of normal marking procedure. The examination was taken by 150 students, and as all the questions set were compulsory, the performances were directly comparable. The results have been described by P. J. Fensham of the University of Melbourne (Vestes, 4, No. 4; December 1961).

The customary way of assessing performance was in terms of the total percentage for the whole paper. This method gave the following results: honours (1st, 2nd and 3rd combined), 25; pass, 93; fail, 32. These three grades were then analysed by performance in the various classifications, particular atten tion being directed to the difference between honours and pass, and between pass and fail. It was clear that the major factor distinguishing between honours and pass was better performance of the honours group in classes 1,2 and 3 . This group averaged 78 per cent in the first three classes and 70 per cent for the last three, whereas pass students averaged 54 per cent in both sets of classes. However, twelve students who were graded as pass students achieved at least 66 per cent in classes 4,5 and 6 , whereas eight of the students who were awarded honours all scored less than this for those same classes.

A reasonable hypothesis for this type of examination might be that honours should be awarded to those who perform better at the more complex objectives of the last three classes, assuming a cortain competence in the first three. If so, the experiment suggests that the traditional grading by overall percentages involves serious errors in distinguishing between honours and pass students. (A single paper of this type, however, appears unsuit. able to make the distinction, for 70 per cent of it had to be devoted to questions in the first three classes, if the material of the course had to be reasonably covered. This meant there was not enough room left in the paper for a sufficient number of questions of classes 4,5 and 6 .)

So far as the distinction between pass and fail is concerned, it might be reasonable to award a pass for a minimum level of performance in the first three classes, ignoring performance in the other classes 
for this purpose. The results showed that all pass and honours students obtained at least 40 per cent in classes 1,2 and 3 , whereas none of the failed studonts scored more than 40 per cent in these classes. Thus there was no difference in the result-so far as pass and fail were concerned-using this assessment based on the classification as compared with the overall percentage method. There was, however, a sonsiderable difference in the number of honours grades awarded, for different taxonomic gradings, one of which is as follows:

$$
\begin{array}{lccc} 
& \text { Honours } & \text { Pass } & \text { Fail } \\
\text { Overall percentage grading } & 25 & 93 & 32 \\
\text { Taxonomic grading } & 40 & 78 & 32
\end{array}
$$

The conclusion appears to be that considerable care is needed, particularly at the upper end of the scale, if examining is to provide an accurate assessment of what is sought from students.

\section{SALARIES OF UNIVERSITY TEACHING STAFFS IN BRITAIN}

\begin{abstract}
$\mathrm{N}$ a written answer in the House of Commons on March 14, the Chief Secretary to the Treasury, Mr. H. Brooke, stated that the Government had considered the recommendations of the University Grants Committee for recurrent grants for the fiveyear period 1962-67. It had also considered substantial increases in the salaries of univereity teaching staffs with the determination to effect the most rapid development of higher education that is consistent with other claims on the nation's prospective economic resources in the next five years and with the Government's policy for incomes. These considerations had made it necessary to depart from the Committee's recommendations and he had informed the Committee that, subject to annual approval of the Estimates by Parliament in the normal way, it should plan on the basis of the following recurrent grants from August 1 next: $1962-63 £ 56$ million; 1963-64, £60.5 million; $1964-65, \mathfrak{f 6 5 . 5}$ million; 1965-66, £70.5 million; $1966-67, £ 76.5$ million. The grant for the present university year is $£ 49.5$ million. These figures exclude provision for rates, which will be financed by special grants outside the quinquennial settlement, and the cost for the universities of the Grovernment's recent request for an increase in the intake of medical students had yet to be finally settled and would also be additional to these figures.

Mr. Brooke reaffirmed the undertakings given last year on the rapidly incroasing provision for nonrecurrent grants and added that the awards to university students from public funds was also continually growing. In sum, the aggregate cost of the universities to public funds had increased from $£ 50$ million to $£ 104$ million during the past five years and might increase by at least $£ 50$ million in the next five years.
\end{abstract}

The universities' estimates, including those of the seven new universities authorized during the present quinquennium, indicated that, given adequate financial support, they would be prepared to work to an expansion of the total student population from about 111,000 in $1961-62$ to about 150,000 in 1966-67. Mr. Brooke had asked the University Grants Committee to inform the universities that it was the Government's wish that the additional funds should be applied so far as possible to achieving the figure of 150,000 . The Government's aim was to continue the expansion to about 170,000 places by $1973-74$. These recurrent grant figures are based on rates of academic salaries which came into effect in January 1960. The Government had taken carefully into account the strong arguments advanced by the University Grants Committee for a substantial increase in these salaries, along with the need to expand the teaching staff in relation to the increase in student numbers, but did not feel able to authorize an increase of more than 3 per cent in the bill for academic salaries. Scales based on an aggregate increase of this order would be authorized from April 1, 1962, and would cost about $£ 1$ million extra in the first full year. The scales would be reviewed afresh next year. Provision for university expansion was only part of the resources that the Government was devoting, on an increasing scale, to higher education; and all these programmes might need to be re-examined in two or three years' time in the light of the report of the Robbins' Committee on Higher Education. The Government's proposals for the first year of the new quinquennium and for the increase in salaries would necessitate a supplementary estimate of some $£ 4.5$ million for $1962-63$.

\section{RHEOLOGY OF CLAY SOILS}

\begin{abstract}
$\mathrm{T}$ the meeting of the Cambridge Rheology Club held on February 5, Mr. W. J. Thompson Department of Engineering, University of Cambridge) spoke on the "Rheology of Clay Soils". He pointed out that it is current practice in soil mechanics to use the triaxial apparatus to study the shear characteristics of a soil. In this apparatus a cylindrical sample of soil can be subjected to any desired combination of axial and hydrostatic stresses, the sample being either allowed to drain during the deformation process (drained test) or be maintained at a constant volume (undrained test). The allowable shear strength value used in soil mechanics com.
\end{abstract}

putations is taken as some proportion of the maximum shear stress $\tau_{m}$ obtained in a constant axial strainrate triaxial test, although corresponding tests with constant axial stress have indicated that for stresses $>0.8 \tau_{m}$ a state of structural disintegration is obtained. Consideration should therefore be given only to the region of the stress-range $\left(<0.8 \tau_{m}\right)$ within which the soil would behave in the field. Present shear theories are generally based on the results of constant strain-rate tests and neglect time considerations.

The existence of a yield-point in the shear deformation of clays, as investigated by Bingham and scott 